\title{
Possible Antidepressant Effects of Memantine-Systematic Review with a Case Study
}

\author{
Marek Krzystanek ${ }^{1}{ }^{1}$, Stanisław Surma ${ }^{1}$, Artur Pałasz ${ }^{2}$, Monika Romańczyk ${ }^{1}$ and Krzysztof Krysta ${ }^{1}$ D \\ 1 Department of Psychiatry and Psychotherapy, Clinic of Psychiatric Rehabilitation, Faculty of Medical Sciences \\ in Katowice, Medical University of Silesia, Ziołowa 45/47, 40-635 Katowice, Poland; \\ stasiu.surma@onet.eu (S.S.); romanczykmonika@wp.pl (M.R.); Ochojec@gmail.com (K.K.) \\ 2 Department of Histology, Faculty of Medical Sciences in Katowice, Medical University of Silesia, \\ Medyków 18, 40-752 Katowice, Poland; artiassone@gmail.com \\ * Correspondence: m.krzystanek@sum.edu.pl or krzystanekmarek@gmail.com; Tel.: +48-693-281-021; \\ Fax: +48-322-059-260
}

check for updates

Citation: Krzystanek, M.; Surma, S.; Pałasz, A.; Romańczyk, M.; Krysta, K. Possible Antidepressant Effects of Memantine-Systematic Review with a Case Study. Pharmaceuticals 2021, 14, 481. https://doi.org/10.3390/ ph14050481

Academic Editor: Félix Carvalho

Received: 14 April 2021

Accepted: 17 May 2021

Published: 18 May 2021

Publisher's Note: MDPI stays neutral with regard to jurisdictional claims in published maps and institutional affiliations.

Copyright: (c) 2021 by the authors. Licensee MDPI, Basel, Switzerland. This article is an open access article distributed under the terms and conditions of the Creative Commons Attribution (CC BY) license (https:// creativecommons.org/licenses/by/ $4.0 /)$.

\begin{abstract}
The treatment of bipolar depression is hampered by the inadequate efficacy of antidepressants, moderate effect of mood stabilizers, and the side effects of some second-generation antipsychotics. There is limited evidence to date regarding the antidepressant effects of memantine in bipolar depression. The aim of the article was to provide a short review of preclinical and clinical studies on the antidepressant effect of memantine, and to present the case of a bipolar depression patient successfully treated with memantine. The described patient with bipolar disorder was unsuccessfully treated with two mood stabilizers. The addition of memantine at a dose of $20 \mathrm{mg} / \mathrm{d}$ to the treatment with lamotrigine and valproic acid resulted in a reduction in the severity of depression measured on the HDRS-17 scale by $35 \%$, and by $47.1 \%$ after 7 weeks. The discussion presents experimental evidence for the antidepressant effect of memantine, as well as data from clinical trials in recurrent and bipolar depression. The presented case is the second report in the medical literature showing the antidepressant effect of memantine as an add-on treatment for bipolar depression. The described case and literature analysis indicate that memantine may be an effective and safe method of augmentation of mood stabilizing therapy in bipolar depression.
\end{abstract}

Keywords: memantine; bipolar depression; bipolar disorder; augmentation; mood stabilizers; amantadine derivative

\section{Introduction}

Treating depression in bipolar disorder (BD) is a difficult clinical task. One of the main problems in treating depression in bipolar disorder is, on the one hand, the ineffectiveness of antidepressants and, on the other hand, the moderate antidepressant efficacy of mood-stabilizing drugs [1]. Additionally, the use of antidepressants in bipolar depression is generally contraindicated, because they may increase cycle acceleration, causing a rapid cycling course, and contribute to the formation of mixed episodes [1,2]. Attempts to treat bipolar depression with second-generation antipsychotic drugs such as quetiapine and olanzapine may in turn be associated with the risk of deterioration of the functioning of patients, caused by the occurrence of metabolic, motoric, and cognitive side effects; however, the effects of using in aripiprazole and lurasidone are promising in this indication [2]. For this reason, it is imperative to search for new drugs to treat bipolar depression.

Memantine, as well as the structurally analogous adamantane derivative of amantadine [3], is an uncompetitive, low-affinity, and selective open-channel blocker of NMDA receptor (NMDAR). The mechanism of action of memantine is very complex, which may indicate its potential in regulating processes in the central nervous system and, consequently, in the treatment of mental disorders.

Because the relatively fast off-rate accumulation of memantine in the channel pore does not occur, the synaptic transmission is not substantially affected [4]. Unlike ketamine, 
another and well-known NMDAR channel blocker, memantine does not exhibit serious side effects and its inhibitory effect seems to be stereospecific. Memantine binding to the channel pore is considered voltage-independent, and its molecule forms hydrogen bonds with the $\mathrm{N}+1$ asparagine residue (N613 of GluN2B.) [5]. Because alterations in the NMDAR activity can modulate neuronal excitability, even limited differences in the channel blockers' modes of action can distinctly change their clinical properties [6]. The blockade of presynaptic NMDARs in the dopaminergic neurons inhibits dopamine transporter (DAT1) activity and subsequently indirectly increases the dopamine level within the synaptic cleft. Moreover, memantine enhances hippocampal long-term potentiation (LTP) in mice by an increase in CaMKII activity and inhibits ATP-sensitive inward-rectifier $\mathrm{K}_{\mathrm{ir}} 6.1$ and $\mathrm{K}_{\mathrm{ir}} 6.2$ potassium channels in the cultured neurons [7].

A stimulatory effect of memantine on histamine neurons was also reported with up-regulations of brain-derived neurotrophic factor (BDNF) and NMDAR NR1 subunit mRNAs in the hippocampus. The gene expression of $\alpha 7$-nicotinic receptors remained unaffected in any brain structure [8]. It is important to note that memantine may also reduce glutamate release, probably via the inhibition of presynaptic voltage-gated calcium channels (VGCC) and the subsequent blockade of protein kinase C (PKC)-dependent signaling [9]. The drug potently supports the synthesis of kynurenic acid through the activation of protein kinase A (PKA) shown in cortical rat brain slices. The same effect was also described in mixed glial cultures. Kynurenic acid, a neuronal tryptophan derivative, is a blocker of the NMDAR glycine site and an antagonist of nicotinic alpha7 receptors [10]. Noteworthy, memantine highly increases neural progenitor proliferation and stimulates adult neurogenesis in the mouse hippocampus, and it may reduce the activation of microglia and amyloidogenesis in 13-month-old APP/PS1 mice [11]. A summary of the memantine mechanisms of action is shown in Figure 1.

The meta-analysis by Kishi et al. published in 2017 and including six randomized clinical trials, assessed the efficacy of memantine in the treatment of depression [12]. This meta-analysis covered 451 patients with major depressive disorders-four trials $(n=189)$, three of which studied memantine augmentation for antidepressants or bipolar disorder, and two trials $(n=262)$, both on memantine augmentation for mood stabilizers. The mean study duration was 8.33 weeks, and the mean age of patients was 39.9 years. The meta-analysis showed that memantine was not superior to placebo with regard to the response rate $(\mathrm{RR}=0.92,95 \% \mathrm{CI}=0.70-1.20, \mathrm{I} 2=72 \%)$, remission rate (major depressive disorder: RR 0.94; (95\% CI 0.62-1.42, I2 = 80\%); bipolar disorder: RR 0.83; (95\% CI 0.57-1.19, I $2=36 \%)$ ), improvement of depressive symptoms scale score, and all-cause discontinuation $(\mathrm{RR}=0.84,95 \% \mathrm{CI}=0.60-1.18, \mathrm{I} 2=0 \%)$. In conclusion, the authors stated that memantine does not improve the treatment efficacy for depressive symptoms in major depressive disorders and bipolar disorder patients [12].

Despite this, there are studies in the literature that show the possible antidepressant effect of memantine in bipolar depression [13-16]. We recently published a case series study showing the effectiveness of treating bipolar depression with amantadine [17]. Now, we would like to present a case in which amantadine was not effective and the patient was successfully treated with memantine-a drug similar both structurally and in the mechanism of action to amantadine. Moreover, to justify the use of memantine in BD and to help interpret the results of memantine treatment in the case report, we also decided to briefly review the preclinical and clinical evidence for the antidepressant effects of memantine, paying particular attention to the treatment of the depressive phase of BD. 


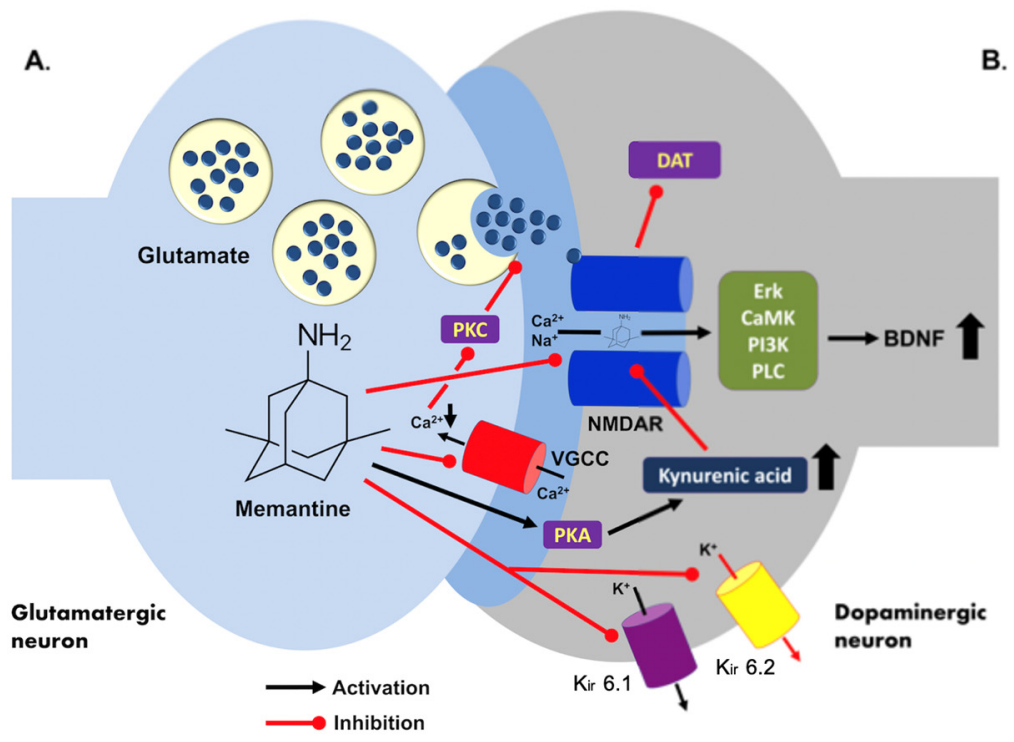

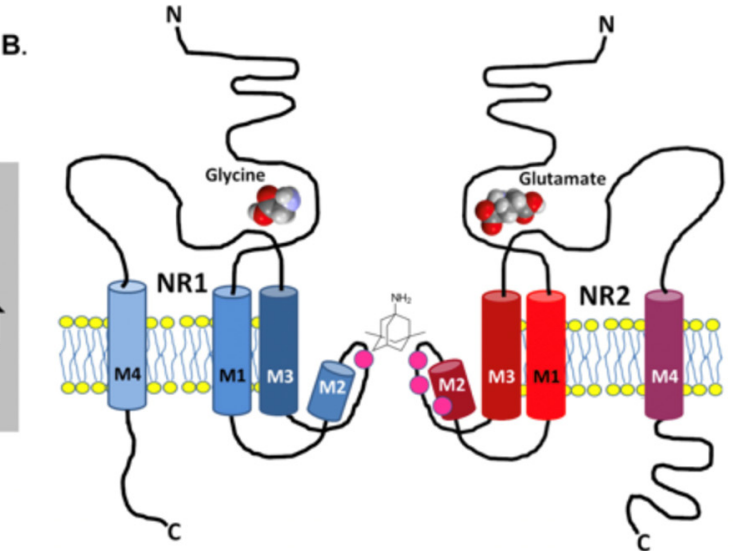

NMDA Receptor

Figure 1. Molecular mechanism of memantine action. (A) The memantine molecule acts as a blocker of the NMDAR ionic channel and it is able to regulate the synaptic dopamine concentration via the inhibition of the presynaptic dopamine transporter (DAT1) activity. Moreover, the blockade of the NMDAR function causes an upregulation of BDNF expression via the Erk, CamK, PI3K, and PLC signaling pathways. Memantine can inhibit inwardly rectifying potassium channels $\mathrm{K}_{\mathrm{ir}} 6.1$ and $\mathrm{K}_{\mathrm{ir}}$ 6.2, and may also decrease voltage-gated calcium channels (VGCC)-dependent glutamate exocytosis. A synthesis of kynurenic acid is stimulated by memantine through the activation of protein kinase A (PKA). (B) Schematic NMDAR structure in the context of memantine action. Two receptor subunits (NR1 and NR2) are presented (transmembrane domains marked in blue and red, respectively) with their glycine and glutamate binding sites (ligand molecules included). Asparagine residues involved in channel blockade by $\mathrm{Mg}^{2+}$ and several inhibitors including memantine are shown. Based on Sing et al. (2018), modified. NMDAR—NMDA receptor; PKA—protein kinase A; PKC—protein kinase C; PLC—phospholipase C; Er-extracellular signal-regulated kinases; BDNF-brain derived neurotrophic factor; PI3K—phosphoinositide 3-kinase; CamK—calcium/calmodulin-dependent protein kinase. Up and down thick arrows indicate the direction of changes.

\section{Results}

\subsection{Preclinical Studies of Antidepressant Effect of Memantine}

Summary of the preclinical evidence of the antidepressant effect of memantine was presented in Table 1.

Table 1. Summary of experimental studies evaluating the antidepressant effect of memantine.

\begin{tabular}{|c|c|c|c|c|c|c|}
\hline Author & Year & Behavioral Model & $\begin{array}{c}\text { Animal } \\
\text { Used }\end{array}$ & $\begin{array}{c}\text { Dose of } \\
\text { Memantine }\end{array}$ & Duration & Conclusions \\
\hline $\begin{array}{l}\text { Moryl } \\
\text { et al. [18] }\end{array}$ & 1993 & Forced swim test & rat & $\begin{array}{c}5,10, \text { and } 20 \\
\mathrm{mg} / \mathrm{kg}\end{array}$ & $\begin{array}{l}24,5 \text {, and } 1 \mathrm{~h} \text { before the } \\
\text { forced swim test }\end{array}$ & $\begin{array}{l}\text { Memantine dose dependently decreased the } \\
\text { duration of immobility time in rats. Moreover, } \\
\text { memantine showed an antidepressant-like activity. }\end{array}$ \\
\hline $\begin{array}{l}\text { Rogóż } \\
\text { et al. [19] }\end{array}$ & 2002 & $\begin{array}{c}\text { Forced swimming } \\
\text { test }\end{array}$ & rat & $\begin{array}{l}5 \mathrm{mg} / \mathrm{kg} \text { and } \\
2.5 \mathrm{mg} / \mathrm{kg}\end{array}$ & $\begin{array}{l}24,5 \text {, and } 1 \mathrm{~h} \text { before the } \\
\text { forced swim test }\end{array}$ & $\begin{array}{l}\text { Memantine, in combination with imipramine, } \\
\text { fluoxetine, and venlafaxine, produced significant } \\
\text { more enhanced antidepressant effect in rats than } \\
\text { each of these drugs alone. }\end{array}$ \\
\hline $\begin{array}{l}\text { Almeida } \\
\text { et al. [20] }\end{array}$ & 2006 & $\begin{array}{l}\text { Forced swimming } \\
\text { test }\end{array}$ & mice & $3-10 \mathrm{mg} / \mathrm{kg}$ & $\begin{array}{l}30 \text { min before the forced } \\
\text { swim test }\end{array}$ & $\begin{array}{c}\text { Acute antidepressant-like effect of memantine } \\
\text { seemed to be dependent on the cellular signaling } \\
\text { modulated by PKA, CaMKII, and MAPK/ERK, but } \\
\text { not by PKC. }\end{array}$ \\
\hline $\begin{array}{l}\text { Réus et al. } \\
\text { [21] }\end{array}$ & 2010 & $\begin{array}{l}\text { Forced swimming } \\
\text { test }\end{array}$ & rat & $\begin{array}{c}5,10, \text { and } 20 \\
\mathrm{mg} / \mathrm{kg}\end{array}$ & $\begin{array}{l}\text { Both } 2 \text { weeks (chronic } \\
\text { treatment) and one } \\
\text { single time (acute } \\
\text { treatment) }\end{array}$ & $\begin{array}{l}\text { Acute and chronic administration of memantine at } \\
\text { all doses decreased the immobility time of rats, but } \\
\text { only acute treatment with memantine enhanced the } \\
\text { protein levels of BDNF in the rat hippocampus. }\end{array}$ \\
\hline
\end{tabular}


Table 1. Cont.

\begin{tabular}{|c|c|c|c|c|c|c|}
\hline Author & Year & Behavioral Model & $\begin{array}{l}\text { Animal } \\
\text { Used }\end{array}$ & $\begin{array}{c}\text { Dose of } \\
\text { Memantine }\end{array}$ & Duration & Conclusions \\
\hline $\begin{array}{l}\text { Quan et al. } \\
\text { [22] }\end{array}$ & 2011 & $\begin{array}{l}21 \text { days of exposure } \\
\text { to chronic } \\
\text { unpredictable stress }\end{array}$ & rat & $20 \mathrm{mg} / \mathrm{kg}$ & 3 weeks & $\begin{array}{l}\text { Memantine improved the sucrose consumption, } \\
\text { reversal learning, and prefrontal cortical synaptic } \\
\text { plasticity, but impaired spatial memory, which is } \\
\text { probably due to different extent of up-regulating } \\
\text { NR2B receptor expression in prefrontal cortex and } \\
\text { hippocampus in stressed rats. }\end{array}$ \\
\hline $\begin{array}{l}\text { Réus et al. } \\
\text { [23] }\end{array}$ & 2011 & $\begin{array}{l}40 \text { days of exposure } \\
\text { to chronic mild } \\
\text { stress }\end{array}$ & rat & $20 \mathrm{mg} / \mathrm{kg}$ & 1 week & $\begin{array}{c}\text { Memantine normalized anhedonia, corticosterone } \\
\text { levels, and hypertrophic adrenal gland, and } \\
\text { increased BDNF protein levels in the rat prefrontal } \\
\text { cortex. }\end{array}$ \\
\hline $\begin{array}{l}\text { Amidfar } \\
\text { et al. [24] }\end{array}$ & 2017 & $\begin{array}{l}\text { Forced swimming } \\
\text { test }\end{array}$ & rat & $\begin{array}{c}2.5 \text { and } 5 \\
\mathrm{mg} / \mathrm{kg}\end{array}$ & 2 weeks & $\begin{array}{l}\text { Co-administration of antidepressant memantine } \\
\text { with sertraline induced a more pronounced } \\
\text { antidepressant activity than treatment with each } \\
\text { antidepressant alone. Antidepressant properties } \\
\text { using the combination of memantine and sertraline } \\
\text { could be attributed to increased levels of BDNF. }\end{array}$ \\
\hline $\begin{array}{l}\text { Amidfar } \\
\text { et al. [25] }\end{array}$ & 2018 & $\begin{array}{l}10 \text { days of exposure } \\
\text { to repeated } \\
\text { unpredictable stress }\end{array}$ & rat & $20 \mathrm{mg} / \mathrm{kg}$ & 2 weeks & $\begin{array}{l}\text { The administration of memantine reversed } \\
\text { depression-like behavior and memory impairment, } \\
\text { and significantly increased BDNF and TrkB mRNA } \\
\text { levels in both the prefrontal cortex and hippocampus } \\
\text { of stress exposed rats. }\end{array}$ \\
\hline $\begin{array}{l}\text { Li et al. } \\
\text { [26] }\end{array}$ & 2020 & $\begin{array}{l}3 \text { weeks } \\
\text { corticosterone } \\
\text { or/and copper } \\
\text { gluconate } \\
\text { administration }\end{array}$ & rat & $20 \mathrm{mg} / \mathrm{kg}$ & 2 weeks & $\begin{array}{l}\text { The results of behavioral tests and cognitive function } \\
\text { after memantine treatment were significantly } \\
\text { normalized, and the copper concentration was } \\
\text { decreased in all of the groups. }\end{array}$ \\
\hline
\end{tabular}

\subsection{Clinical Studies on Antidepressant Effect of Memantine}

Summary of clinical evidence of antidepressant effect of memantine was presented in Table 2.

Table 2. Summary of randomized and non-randomized clinical trials (RCT and non-RCT, respectively) evaluating the efficacy of memantine in the treatment adjunctive treatment of depression in recurrent depression and bipolar depression. The risk of bias and study quality assessed with the Effective Public Health Practice Project's Quality Assessment Tool for Quantitative Studies (QATQS), and was presented as the global rating for each publication (1—strong; 2 -moderate; 3-weak).

\begin{tabular}{|c|c|c|c|c|c|c|c|c|}
\hline Authors & Year & $\begin{array}{l}\text { Type of } \\
\text { Study }\end{array}$ & $\begin{array}{l}\text { Sample } \\
\text { Size }\end{array}$ & $\begin{array}{l}\text { Characteristic } \\
\text { of Participants }\end{array}$ & Intervention & Results & Conclusions & $\begin{array}{l}\text { QATQS } \\
\text { Global } \\
\text { Rating }\end{array}$ \\
\hline $\begin{array}{c}\text { Zarate } \\
\text { et al. [27]. }\end{array}$ & 2006 & $\mathrm{RCT}$ & 32 & $\begin{array}{l}\text { Subjects with } \\
\text { major } \\
\text { depression }\end{array}$ & $\begin{array}{c}\text { Memantine }(5-20 \mathrm{mg} / \text { day }) \\
(n=16) \text { or placebo }(n=16) \\
\text { for } 8 \text { weeks. } \\
\text { Primary efficacy was } \\
\text { assessed by performance on } \\
\text { the Montgomery-Asberg } \\
\text { Depression Rating Scale } \\
\text { (MADRS). }\end{array}$ & $\begin{array}{c}\text { The linear mixed models } \\
\text { for total MADRS scores } \\
\text { showed no } \\
\text { treatment effect. }\end{array}$ & $\begin{array}{c}\text { In an 8-week trial, } \\
\text { memantine in doses of } \\
5-20 \mathrm{mg} / \text { day was not } \\
\text { effective in the treatment } \\
\text { of major } \\
\text { depressive disorder. }\end{array}$ & 1 \\
\hline $\begin{array}{l}\text { Ferguson } \\
\text { and Shin- } \\
\text { gleton } \\
\text { [28] }\end{array}$ & 2007 & $\begin{array}{l}\text { Non } \\
\text { RCT }\end{array}$ & 8 & $\begin{array}{l}\text { Subjects with } \\
\text { major } \\
\text { depression }\end{array}$ & $\begin{array}{l}\text { In this } 12 \text {-week subjects } \\
\text { were treated for } 4 \text { weeks to } \\
20 \mathrm{mg} / \mathrm{d} \text { memantine. } \\
\text { Nonresponsive patients } \\
\text { were titrated to } 30 \mathrm{mg} / \mathrm{d} \text { (at } \\
\text { week } 8 \text { ) or } 40 \mathrm{mg} / \mathrm{d} \\
\text { (at week } 10 \text { ). } \\
\text { Outcome measures were } \\
\text { MADRS, HDRS, Clinical } \\
\text { Global Impression-Severity } \\
\text { of Illness and the Clinical } \\
\text { Global Impression- } \\
\text { Improvement Scales, Patient } \\
\text { Global Evaluation, and } \\
\text { Diagnostic and Statistical } \\
\text { Manual of Mental Disorders, } \\
\text { Fourth Edition, Major } \\
\text { Depressive Episode } \\
\text { Checklist. }\end{array}$ & $\begin{array}{l}\text { Baseline MADRS score } \\
\text { was } 31.9 \text { (4.45), indicative } \\
\text { of severe depression. } \\
\text { Seven subjects completed } \\
\text { the study. All patients } \\
\text { attained the target dose of } \\
20 \mathrm{mg} / \mathrm{d} ; 3 \text { patients were } \\
\text { titrated to } 30 \mathrm{mg} / \mathrm{d} \text { after } \\
\text { week } 8 \text {, and } 2 \text { patients } \\
\text { were titrated to } 40 \mathrm{mg} / \mathrm{d} \\
\text { after week } 10 . \text { The mean } \\
\text { dosage across all weeks } \\
\text { was } 18.1 \text { mg. Patients } \\
\text { improved on all efficacy } \\
\text { measures within } 1 \text { week of } \\
\text { treatment initiation. The } \\
\text { mean improvement } \\
\text { peaked at week } 8 \text { and was } \\
\text { maintained through week } \\
12 \text { (MADRS, } 18.5 \text { (10.3)). }\end{array}$ & $\begin{array}{l}\text { Memantine demonstrated } \\
\text { early-onset efficacy in } \\
\text { patients with } \\
\text { major depression. }\end{array}$ & 2 \\
\hline
\end{tabular}


Table 2. Cont.

\begin{tabular}{|c|c|c|c|c|c|c|c|c|}
\hline Authors & Year & $\begin{array}{l}\text { Type of } \\
\text { Study }\end{array}$ & $\begin{array}{l}\text { Sample } \\
\text { Size }\end{array}$ & $\begin{array}{l}\text { Characteristic } \\
\text { of Participants }\end{array}$ & Intervention & Results & Conclusions & $\begin{array}{l}\text { QATQS } \\
\text { Global } \\
\text { Rating }\end{array}$ \\
\hline $\begin{array}{l}\text { Muhonen } \\
\text { et al. [29] }\end{array}$ & 2008 & $\mathrm{RCT}$ & 58 & $\begin{array}{l}\text { Alcohol- } \\
\text { depend- } \\
\text { entoutpatients } \\
\text { with major } \\
\text { depressivedis- } \\
\text { order }\end{array}$ & $\begin{array}{c}\text { In this 26-week study } \\
\text { patients were treated with } \\
\text { memantine } \\
\text { (n=29;20 mg/day) or } \\
\text { escitalopram } \\
(n=29 ; 20 \mathrm{mg} / \text { day). } \\
\text { Outcome measures were } \\
\text { MADRS and Beck } \\
\text { Depression Inventory-II for } \\
\text { depression, Hamilton Rating } \\
\text { Scale for Anxiety (HAM-A) } \\
\text { and Beck Anxiety Inventory } \\
\text { for anxiety, Consortium to } \\
\text { Establish a Registry for } \\
\text { Alzheimer's Disease test } \\
\text { battery for cognitive } \\
\text { functions, and Social and } \\
\text { Occupational Functioning } \\
\text { Assessment Scale for social } \\
\text { and occupational functions } \\
\text { and quality-of-life measures. }\end{array}$ & $\begin{array}{l}\text { Both treatments } \\
\text { significantly reduced the } \\
\text { baseline level of } \\
\text { depression and anxiety } \\
\text { according to MADRS and } \\
\text { HAM-A, which were the } \\
\text { primary measures } \\
(p<0.0001) \text {. There was no } \\
\text { significant difference } \\
\text { between the memantine } \\
\text { and escitalopram groups. } \\
\text { Quality-of-life outcomes } \\
\text { equally improved in both } \\
\text { treatment groups. }\end{array}$ & $\begin{array}{l}\text { These data provide new } \\
\text { evidence for the safety } \\
\text { and potential efficacy of } \\
\text { memantine for major } \\
\text { depressive disorder in } \\
\text { patients with comorbid } \\
\text { alcohol dependence. }\end{array}$ & 1 \\
\hline $\begin{array}{l}\text { Anand } \\
\text { et al. [13] }\end{array}$ & 2012 & $\mathrm{RCT}$ & 29 & $\begin{array}{l}\text { Subjects with } \\
\text { depressive } \\
\text { phase of } \\
\text { bipolar } \\
\text { disorder }\end{array}$ & $\begin{array}{l}\text { Subjects on a stable dose of } \\
\text { lamotrigine (100 mg or } \\
\text { more) were randomized to } \\
\text { either memantine (starting } \\
\text { dose of } 5 \mathrm{mg} \text { increased up to } \\
20 \mathrm{mg} \text { over four weeks, then } \\
20 \mathrm{mg} \text { stable dose from four } \\
\text { to eight weeks) or matching } \\
\text { pill placebo for eight } \\
\text { weeks.Patients were rated on } \\
\text { the } 17 \text {-item HDRS and other } \\
\text { behavioral measures weekly. }\end{array}$ & $\begin{array}{l}\text { The 8-week } \\
\text { repeated-measures } \\
\text { mixed-effect model for } \\
\text { HDRS was not significant } \\
\text { for memantine } v s \text {. the } \\
\text { placebo. Exploratory } \\
\text { mixed-effect analyses for } \\
\text { the first } 4 \text { weeks while the } \\
\text { memantine dose was } \\
\text { being titrated up every } \\
\text { week revealed a } \\
\text { significant decrease in } \\
\text { HDRS scores from } \\
\text { baseline }(p=0.007) \text {. }\end{array}$ & $\begin{array}{l}\text { No statistically significant } \\
\text { benefit of memantine } \\
\text { augmentation of } \\
\text { lamotrigine for patients } \\
\text { with depressive phase of } \\
\text { bipolar disorder over } \\
\text { eight weeks was } \\
\text { demonstrated. However, } \\
\text { memantine had an } \\
\text { antidepressant effect early } \\
\text { on in the treatment while } \\
\text { its dose was being } \\
\text { titrated up. }\end{array}$ & 1 \\
\hline $\begin{array}{l}\text { Smith } \\
\text { et al. [30] }\end{array}$ & 2013 & $\mathrm{RCT}$ & 31 & $\begin{array}{l}\text { Subjects with } \\
\text { majordepres- } \\
\text { sivedisorder }\end{array}$ & $\begin{array}{l}\text { Subjects were randomized to } \\
\text { add memantine to current } \\
\text { antidepressant treatment } \\
\text { (flexible dose } 5-20 \mathrm{mg} / \mathrm{d} \text {, } \\
\text { with all memantine group } \\
\text { participants reaching the } \\
\text { dose of } 20 \mathrm{mg} / \mathrm{d})(n=15) \text { or } \\
\text { placebo }(n=16) \text { to their } \\
\text { existing treatment for } 8 \\
\text { weeks. } \\
\text { Primary outcome was } \\
\text { measured by MADRS. } \\
\text { Secondary outcomes } \\
\text { included other depression } \\
\text { and anxiety rating scales, } \\
\text { suicidal and delusional } \\
\text { ideation, and other adverse } \\
\text { effects. }\end{array}$ & $\begin{array}{l}\text { Participants receiving } \\
\text { memantine did not show } \\
\text { a statistically or clinically } \\
\text { significant change in } \\
\text { MADRS scores compared } \\
\text { with the placebo over the } \\
\text { entire study. Similarly, no } \\
\text { substantial effect sizes } \\
\text { favoring memantine, nor } \\
\text { statistically significant } \\
\text { between-group } \\
\text { differences, were observed } \\
\text { for the secondary efficacy } \\
\text { outcomes. }\end{array}$ & $\begin{array}{l}\text { This trial did not detect } \\
\text { significant statistical or } \\
\text { effect size differences } \\
\text { between memantine and } \\
\text { placebo augmentation } \\
\text { among non-responders or } \\
\text { poor responders to } \\
\text { conventional } \\
\text { antidepressants. }\end{array}$ & 1 \\
\hline $\begin{array}{l}\text { Strzelecki } \\
\text { et al. [15] }\end{array}$ & 2013 & $\begin{array}{l}\text { case } \\
\text { report }\end{array}$ & 1 & $\begin{array}{l}\text { 49-year-old } \\
\text { male with } \\
\text { manic } \\
\text { moderate } \\
\text { depressive } \\
\text { episode }\end{array}$ & $\begin{array}{l}\text { After an ineffective use of } \\
\text { lithium, olanzapine and } \\
\text { antidepressant treatment } \\
\text { with mianserin, memantine } \\
\text { was added up to } 20 \text { mg per } \\
\text { day for } 10 \text { weeks. } \\
\text { The mental state was } \\
\text { assessed using the HDRS, } \\
\text { the Young Mania Rating } \\
\text { Scale (YMRS), the HAM-A, } \\
\text { the Clinical Global } \\
\text { Inventory, the World Health } \\
\text { Organization Quality of Life } \\
\text { Scale and psychological } \\
\text { tests. }\end{array}$ & $\begin{array}{l}\text { After } 10 \text { weeks, the } \\
\text { patient achieved a partial } \\
\text { symptomatic } \\
\text { improvement in mood, } \\
\text { anxiety, and quality of } \\
\text { sleep, but his activity } \\
\text { remained insufficient. We } \\
\text { also observed an } \\
\text { improvement in the } \\
\text { parameters of cognitive } \\
\text { functioning and quality of } \\
\text { life. }\end{array}$ & $\begin{array}{l}\text { Using memantine in } \\
\text { bipolar depression may } \\
\text { improve mood, cognitive } \\
\text { functioning, and quality } \\
\text { of life. }\end{array}$ & 3 \\
\hline
\end{tabular}


Table 2. Cont.

\begin{tabular}{|c|c|c|c|c|c|c|c|c|}
\hline Authors & Year & $\begin{array}{l}\text { Type of } \\
\text { Study }\end{array}$ & $\begin{array}{l}\text { Sample } \\
\text { Size }\end{array}$ & $\begin{array}{l}\text { Characteristic } \\
\text { of Participants }\end{array}$ & Intervention & Results & Conclusions & $\begin{array}{l}\text { QATQS } \\
\text { Global } \\
\text { Rating }\end{array}$ \\
\hline $\begin{array}{l}\text { Stevens } \\
\text { et al. [16] }\end{array}$ & 2013 & RCT & 29 & $\begin{array}{l}\text { Bipolar } \\
\text { depression } \\
\text { patients }\end{array}$ & $\begin{array}{l}\text { Patients on a stable dose of } \\
\text { lamotrigine were } \\
\text { randomized } 1: 1 \text { to receive } \\
\text { memantine } 20 \mathrm{mg} / \text { day and } \\
\text { placebo. The study lasted } \\
4-8 \text { weeks in the memantine } \\
\text { group and } 8 \text { weeks in the } \\
\text { placebo group. The severity } \\
\text { of depression was measured } \\
\text { with the HDRS-17 scale. }\end{array}$ & $\begin{array}{l}\text { There were no differences } \\
\text { in change in the HDRS-17 } \\
\text { score between the groups. } \\
\text { In the group treated with } \\
\text { memantine, an } \\
\text { acceleration of speed of } \\
\text { response in HDRS-17 was } \\
\text { shown. } 12 \text { patients } \\
\text { improved in memantine } \\
\text { group and } 6 \text { in placebo } \\
\text { group. No relapses were } \\
\text { observed in the } \\
\text { memantine group. }\end{array}$ & $\begin{array}{l}\text { Memantine added to } \\
\text { lamotrigine caused an } \\
\text { increased speed of } \\
\text { response compared with } \\
\text { placebo in bipolar } \\
\text { depression patients. }\end{array}$ & 1 \\
\hline $\begin{array}{l}\text { Omranifard } \\
\text { et al. [31] }\end{array}$ & 2014 & $\mathrm{RCT}$ & 57 & $\begin{array}{l}\text { Subjects with } \\
\text { depression }\end{array}$ & $\begin{array}{l}\text { Memantine ( } 20 \text { mg daily) or } \\
\text { identical placebo plus } \\
\text { citalopram for } 8 \text { weeks. } \\
\text { Severity of depression and } \\
\text { quality of life was evaluated } \\
\text { using the Geriatric } \\
\text { Depression Scale (GDS-15) } \\
\text { HDRS and World Health } \\
\text { Organization Quality of Life } \\
\text { WHOQOL-BREF, } \\
\text { respectively. }\end{array}$ & $\begin{array}{l}\text { The scores of the GDS-15, } \\
\text { HRSD, and } \\
\text { WHO-QOL-BREF scales at } \\
\text { baseline, } 4 \text { weeks, and } 8 \\
\text { weeks after initiating the } \\
\text { trial did not change } \\
\text { significantly after the use } \\
\text { of memantine }(p>0.05) \text {. } \\
\text { There was no significant } \\
\text { difference in mean } \pm \text { SD } \\
\text { of GDS-15, HRSD, and } \\
\text { WHO-QOL-BREF scales } \\
\text { among the intervention } \\
\text { and placebo groups } \\
(p>0.05) \text {. }\end{array}$ & $\begin{array}{l}\text { The outcome of this } \\
\text { clinical trial did not } \\
\text { support the } \\
\text { antidepressant effect of } \\
\text { add-on memantine in } \\
\text { elderly patients with } \\
\text { depression } \\
\text { receiving citalopram. }\end{array}$ & 1 \\
\hline $\begin{array}{l}\text { Lee et al. } \\
\text { [14] }\end{array}$ & 2014 & $\mathrm{RCT}$ & 232 & $\begin{array}{c}\text { Subjects with } \\
\text { bipolardisor- } \\
\text { der II } \\
\text { depression }\end{array}$ & $\begin{array}{l}\text { During the } 12 \text {-week study, } \\
\text { patients undergoing regular } \\
\text { valproic acid treatments } \\
\text { were randomly assigned to a } \\
\text { group: valproic acid }+ \\
\text { memantine ( } 5 \text { mg/day) } \\
\text { ( } n=115 \text { ) or valproic acid + } \\
\text { placebo }(n=117) \text {. } \\
\text { The HDRS and YMRS were } \\
\text { used to evaluate the clinical } \\
\text { responses during weeks } 0,1 \text {, } \\
2,4,8 \text {, and } 12 \text {. } \\
\text { The genotypes of the } \\
\text { brain-derived neurotrophic } \\
\text { factor (BDNF) Val66Met } \\
\text { polymorphisms were } \\
\text { determined using } \\
\text { polymerase chain reactions } \\
\text { plus restriction fragment } \\
\text { length polymorphism } \\
\text { analysis. }\end{array}$ & $\begin{array}{l}\text { Both groups showed } \\
\text { significantly decreased } \\
\text { YMRS and HDRS scores } \\
\text { after } 12 \text { weeks of } \\
\text { treatment; the differences } \\
\text { between groups were } \\
\text { non-significant. When } \\
\text { stratified by the BDNF } \\
\text { Val66Met genotypes, } \\
\text { significantly greater } \\
\text { decreases in HDRS scores } \\
\text { were found in the VPA + } \\
\text { memantine group in } \\
\text { patients with the Val Met } \\
\text { genotype ( } p=0.004) .\end{array}$ & $\begin{array}{l}\text { The effectiveness of } \\
\text { memantine in the } \\
\text { treatment of depression } \\
\text { depended on } \\
\text { polymorphisms in the } \\
\text { BDNF gene. }\end{array}$ & 1 \\
\hline $\begin{array}{l}\text { Amidfar } \\
\text { et al. [32] }\end{array}$ & 2017 & $\mathrm{RCT}$ & 66 & $\begin{array}{l}\text { Subjects with } \\
\text { moderate-to- } \\
\text { severe major } \\
\text { depressivedis- } \\
\quad \text { order }\end{array}$ & $\begin{array}{l}6 \text { weeks of treatment with } \\
\text { either memantine } \\
\text { (20 mg/day) plus sertraline } \\
\text { ( } 200 \mathrm{mg} \text { /day) or placebo } \\
\text { plus sertraline ( } 200 \mathrm{mg} / \text { day). } \\
\text { Patients were evaluated } \\
\text { using HDRS at baseline and } \\
\text { at weeks } 2,4 \text {, and } 6 .\end{array}$ & $\begin{array}{l}\text { A significantly greater } \\
\text { improvement was seen at } \\
\text { all three follow-up } \\
\text { sessions, as well as } \\
\text { significantly greater } \\
\text { response rates at weeks } 4 \\
\text { and 6, in the memantine } \\
\text { group. Significantly more } \\
\text { early improvements and } \\
\text { more rapid response to } \\
\text { treatment were observed } \\
\text { in the memantine group. } \\
\text { A significant reduction } \\
\text { was observed in the } \\
\text { HDRS score from baseline } \\
\text { to the study endpoint in } \\
\text { both the memantine and } \\
\text { placebo groups. }\end{array}$ & $\begin{array}{l}\text { A 6-week course of } \\
\text { treatment with memantine } \\
\text { as an adjunct to sertraline } \\
\text { showed a favorable safety } \\
\text { and efficacy profile in } \\
\text { patients with major } \\
\text { depressive disorder. }\end{array}$ & 1 \\
\hline
\end{tabular}


Table 2. Cont.

\begin{tabular}{|c|c|c|c|c|c|c|c|c|}
\hline Authors & Year & $\begin{array}{l}\text { Type of } \\
\text { Study }\end{array}$ & $\begin{array}{c}\text { Sample } \\
\text { Size }\end{array}$ & $\begin{array}{l}\text { Characteristic } \\
\text { of Participants }\end{array}$ & Intervention & Results & Conclusions & $\begin{array}{l}\text { QATQS } \\
\text { Global } \\
\text { Rating }\end{array}$ \\
\hline $\begin{array}{l}\text { Lavretsky } \\
\text { et al. [33] }\end{array}$ & 2020 & $\mathrm{RCT}$ & 62 & $\begin{array}{l}\text { Older adults } \\
\text { with } \\
\text { depression } \\
\text { and subjective } \\
\text { memory } \\
\text { complaints }\end{array}$ & $\begin{array}{l}\text { Escitalopram + memantine } \\
\text { (ESC/MEM) compared with } \\
\text { escitalopram + placebo } \\
\text { (ESC/PBO) for } 6 \text { months. } \\
\text { The primary outcome was a } \\
\text { change in depression, as } \\
\text { assessed by HDRS } \\
\text { post-treatment (at } 6 \text { months). } \\
\text { Remission was defined as } \\
\text { HDRS } \leq 6 \text {; naturalistic } \\
\text { follow-up continued until } \\
12 \text { months. }\end{array}$ & $\begin{array}{c}\text { The mean daily } \\
\text { escitalopram dose was } \\
11.1 \mathrm{mg} \text { (SD = 3.7; range: } \\
\text { 5-20 mg). The mean daily } \\
\text { memantine dose was } 19.3 \\
\text { mg (SD = 2.6; } \\
\text { range } 10-20 \mathrm{mg} \text { ). The } \\
\text { remission rate within } \\
\text { ESC/MEM was } 45.8 \% \text { and } \\
47.9 \% \text {, compared with } \\
38.3 \% \text { and } 31.9 \% \text { in } \\
\text { ESC/PBO, at } 3 \text { and } 6 \\
\text { months, respectively. Both } \\
\text { groups improved } \\
\text { significantly on the } \\
\text { HAM-D at } 3,6 \text {, and } 12 \\
\text { months, with no observed } \\
\text { between-group } \\
\text { differences. ESC } / \text { MEM } \\
\text { demonstrated greater } \\
\text { improvement in delayed } \\
\text { recall and executive } \\
\text { functioning at } 12 \text { months } \\
\text { compared with ESC/PBO. }\end{array}$ & $\begin{array}{l}\text { The combination of } \\
\text { memantine with } \\
\text { escitalopram was well } \\
\text { tolerated and was as } \\
\text { effective as escitalopram } \\
\text { and placebo in improving } \\
\text { depression using HAM-D. } \\
\text { The combination of } \\
\text { memantine and } \\
\text { escitalopram was } \\
\text { significantly more } \\
\text { effective than } \\
\text { escitalopram and the } \\
\text { placebo at improving } \\
\text { cognitive outcomes at } \\
12 \text { months. }\end{array}$ & 1 \\
\hline
\end{tabular}

\subsection{Individual Case Report}

The patient used was 43 years old, and had been suffering from BD since the age of 34. The onset of the disease was not associated with distress, somatic disease, or taking psychoactive substances. When the symptoms of elevated mood and increased drive began, the patient began to abuse amphetamines, but it was already during mania. The patient stopped coming home from work, had new plans, risky money invested, and he also established extra-marital sexual relationships. Mania was diagnosed according to ICD-10. As a result of treatment with quetiapine $(600 \mathrm{mg} / \mathrm{d})$, the symptoms of mania were resolved, the patient took it at a dose of $300 \mathrm{mg}$ for 3 years, and then, in consultation with the doctor, he gradually stopped taking the drug. In the spring of 2017, there was a short 3-day period of hypomania-the patient prolonged his sleep with estazolam in a dose of $2 \mathrm{mg}$ at night for 1 week and the symptoms subsided.

In October 2018, the patient developed hypomania (diagnosis according to ICD-10). The patient was recommended to extend his sleep to $11 \mathrm{~h}$, and he was given estazolam $2 \mathrm{mg}$ at night for 2 weeks. The symptoms resolved, but after a month the patient presented with symptoms of moderate depression (HDRS 18 points). He was given quetiapine again at a target dose of $300 \mathrm{mg}$ at night. After 2 months, his symptoms remained at a similar level (HDRS 18 points). Because of lithium intolerance (nausea and vomiting, a feeling of bitterness in the mouth), he then additionally received lamotrigine at a target dose of $150 \mathrm{mg}$ /day. After another two months, there was no improvement (HDRS 19). It was decided to change the treatment-quetiapine was discontinued and replaced with aripiprazole at a dose of $7.5 \mathrm{mg}$. After another 6 weeks, no improvement was achieved (HDRS 18 points) and the patient continued treatment with lamotrigine $150 \mathrm{mg}$ and aripiprazole $7.5 \mathrm{mg}$ for another 6 weeks. As a result of the lack of improvement (HDRS 19), aripiprazole was discontinued and valproic acid was added to the treatment, titratedup to $1500 \mathrm{mg} /$ day. At the next visit after 3 months, the patient still had a depressive episode of a similar intensity as before (HDRS 18 points). The patient then consented to treatment with amantadine. Initially, he took $100 \mathrm{mg}$ in the morning and $200 \mathrm{mg}$ in the morning after a week. After about 10 days on a dose of $200 \mathrm{mg}$, the patient felt a slight improvement (HDRS 15) and the treatment was continued for another month. After one month, the HDRS was 17 points (Table 1).

Amantadine was discontinued and treatment with memantine was proposed, at a target dose of $20 \mathrm{mg}$. The patient was informed about the mechanism of action of memantine, 
its potential side effects, and the off-label use of the drug before starting it. The patient consented to add-on treatment with memantine. The dose was increased gradually by $5 \mathrm{mg}$ every 3 days. After 2 weeks on a dose of $20 \mathrm{mg}$, the patient reported feeling a little better, but the psychiatric evaluation of the HDRS was 16 points. After another week, the total score on HDRS-17 decreased to 13 points, and after another week to 11 points. When he came for an appointment after another month of treatment, the HDRS was 9 points. The patient reported that he had not felt so well in a long time. A weekly reduction of memantine was started by $5 \mathrm{mg}$, but the patient started to feel worse on the $5 \mathrm{mg}$ dose (HDRS 13) and the dose was then increased to $10 \mathrm{mg}$. At the next visit after one month, the HDRS score was 7 points (Table 3 and Figure 2). Treatment did not change since then. From the beginning of the treatment, the patient tolerated the treatment with memantine well and no side effects were observed. The patient is still in stable remission.

Table 3. Drugs used in the treatment of a patient with memantine treated with bipolar depression, with severity of depression measured with HDRS-17.

\begin{tabular}{ccc}
\hline Visit Time & HDRS-17 (Points) & Treatment (Daily Dose) \\
\hline $11 / 2018$ & 18 & quetiapine $300 \mathrm{mg}$ \\
\hline $01 / 2019$ & 18 & quetiapine $300 \mathrm{mg}+$ lamotrigine $150 \mathrm{mg}$ \\
\hline $03 / 2019$ & 19 & lamotrigine $150 \mathrm{mg}+$ aripiprazol $7.5 \mathrm{mg}$ \\
\hline $05 / 2019$ & 18 & lamotrigine $150 \mathrm{mg}+$ aripiprazol $7.5 \mathrm{mg}$ \\
\hline $07 / 2019$ & 19 & lamotrigine $150 \mathrm{mg}+$ valproic acid $1500 \mathrm{mg}$ \\
\hline $10 / 2019$ & 18 & lamotrigine $150 \mathrm{mg}+$ valproic acid $1500 \mathrm{mg}+$ amantadine \\
\hline $10 / 2019$ & 15 & lamotrigine $150 \mathrm{mg}+$ valproic acid $1500 \mathrm{mg}+$ amantadine $200 \mathrm{mg}$ \\
\hline $11 / 2019$ & 17 & lamotrigine $150 \mathrm{mg}+$ valproic acid $1500 \mathrm{mg}+\mathrm{memantine}$ \\
& titrated-up every 3 days $(5 \mathrm{mg} / 10 \mathrm{mg} / 15 \mathrm{mg} / 20 \mathrm{mg})$ \\
\hline $11 / 2019$ & 16 & lamotrigine $150 \mathrm{mg}+$ valproic acid $1500 \mathrm{mg}+\mathrm{memantine} 20 \mathrm{mg}$ \\
\hline $12 / 2019$ & 13 & lamotrigine $150 \mathrm{mg}+$ valproic acid $1500 \mathrm{mg}+\mathrm{memantine} 20 \mathrm{mg}$ \\
\hline $01 / 2020$ & 11 & lamotrigine $150 \mathrm{mg}+$ valproic acid $1500 \mathrm{mg}+\mathrm{memantine} 20 \mathrm{mg}$ \\
\hline $02 / 2020$ & 9 & lamotrigine $150 \mathrm{mg}+$ valproic acid $1500 \mathrm{mg}+\mathrm{memantine} 20 \mathrm{mg}$ \\
\hline $03 / 2020$ & 13 & lamotrigine $150 \mathrm{mg}+$ valproic acid $1500 \mathrm{mg}+\mathrm{memantine} 5 \mathrm{mg}$ \\
\hline
\end{tabular}

Adding memantine to the patient's for treatment with two mood stabilizers resulted in an improvement and subsequent relief of depressive symptoms. Table 3 and Figure 3 show the course of treatment and changes in the severity of depression measured with HDRS-17 during the treatment of a BD patient with an episode of bipolar depression. 


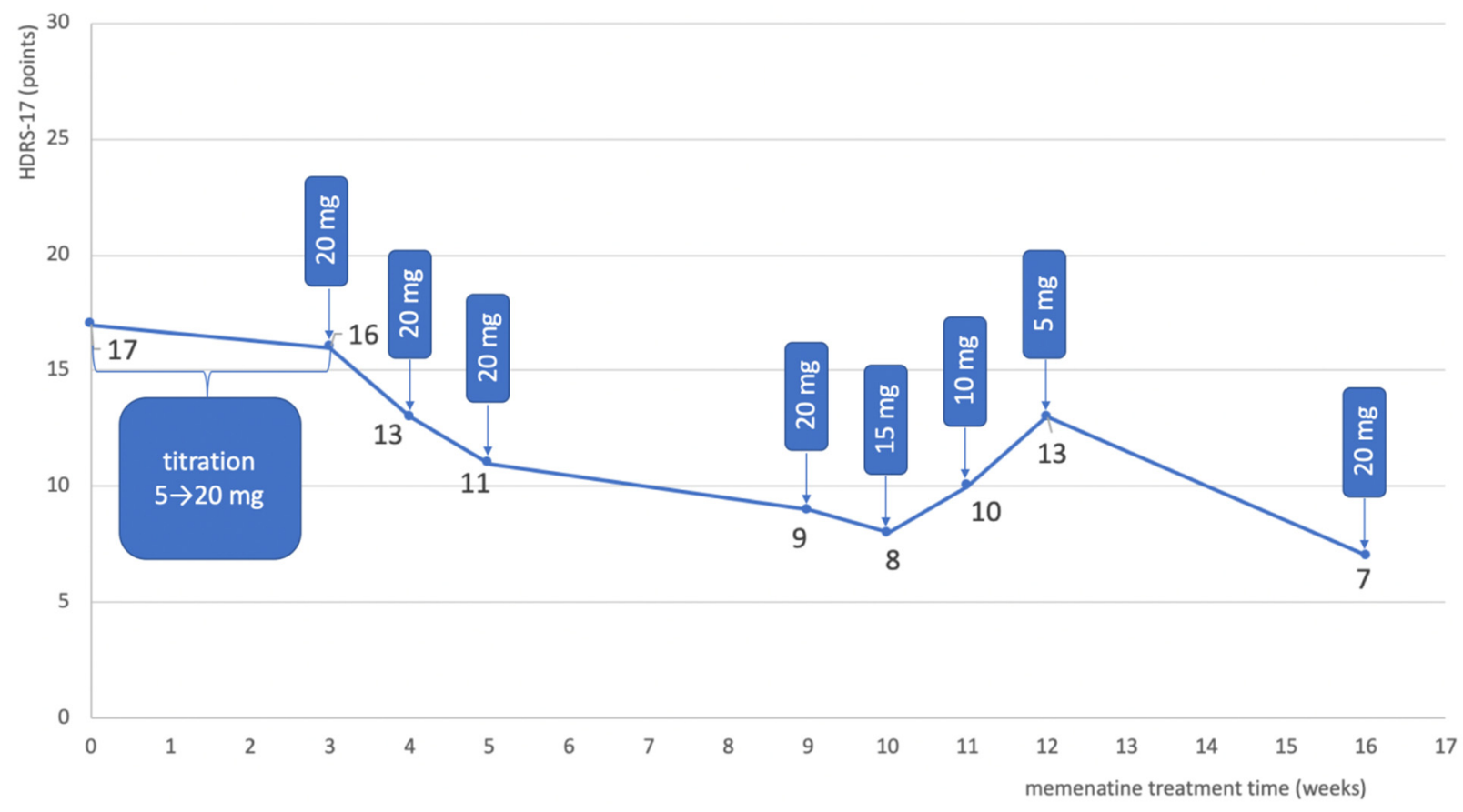

Figure 2. Change in the severity of depression in the bipolar depression patient, measured with the HDRS-17 scale during treatment, depending on the duration of treatment and the dose of memantine.
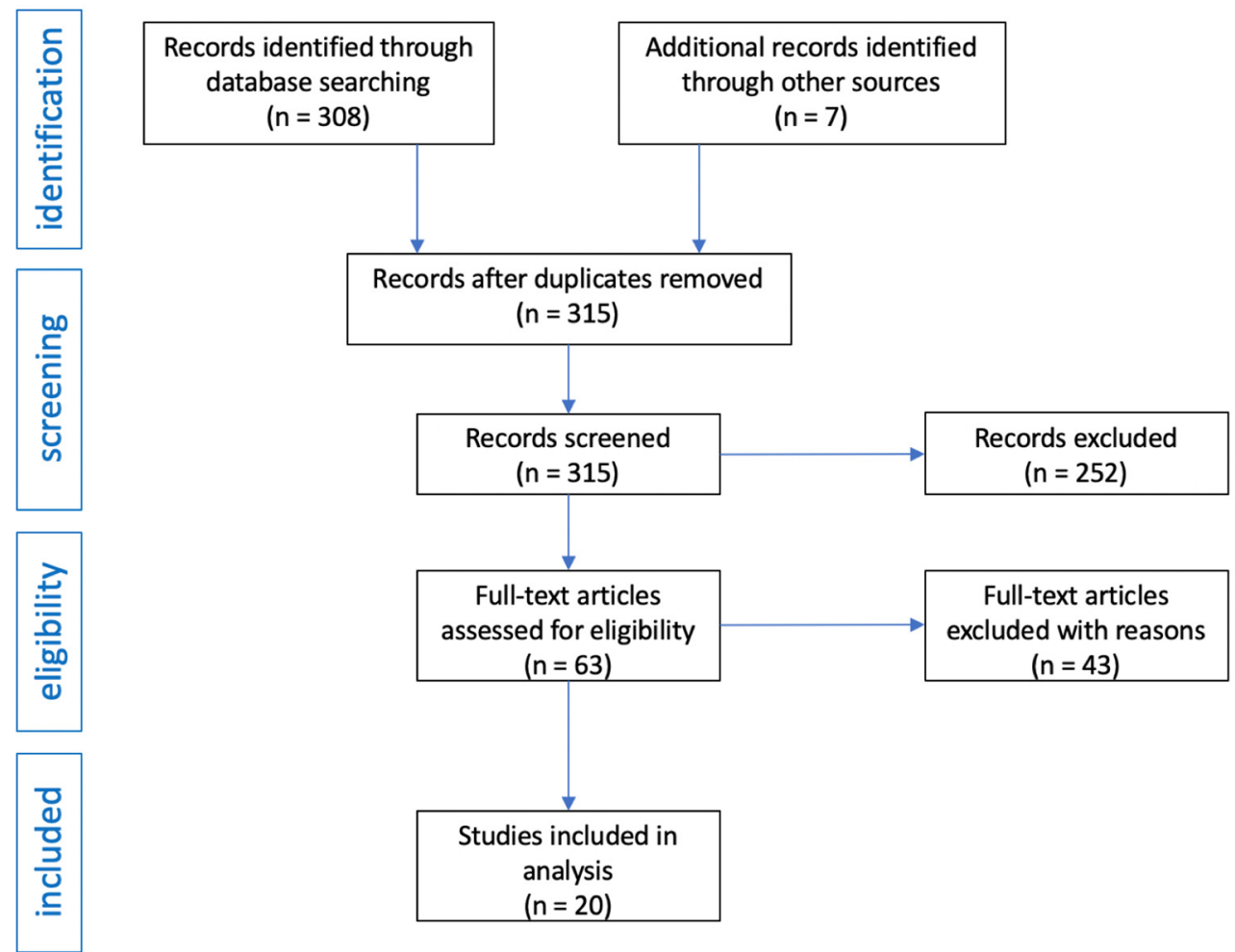

Figure 3. Preferred reporting items for the systematic reviews flow diagram.

\section{Discussion}

All nine experimental studies conducted so far on animal models of depression have shown the antidepressant effect of memantine [18-26]. It is therefore surprising that most clinical trials carried out later failed to confirm the antidepressant effect of memantine 
in monotherapy and as an add-on treatment $[13,27,30,31]$. Despite the negative results of the meta-analysis conducted in 2017 by Kish et al., there are publications pointing to the possible antidepressant effect of memantine in augmenting the treatment of recurrent depression $[28,29,32]$; however, they may be related to certain subtypes of depression, e.g., in the course of alcohol dependence [29] or in the improvement of symptoms of cognitive impairment in depression [33]. Importantly, there is a lack of new clinical trials on the efficacy of memantine in depression, and most of the studies presented are from 5 years ago.

In bipolar depression, memantine has been shown to be effective in the dose titrationup stage [13]. A study by Stevens et al. showed that memantine accelerates the action of lamotrigine [16]. One study also showed that the effectiveness of add-on treatment with memantine is effective in patients with Val66Met polymorphism in the BDNF gene [14]. In 2013, Strzelecki et al. described the case of a patient suffering from bipolar depression, in which memantine proved to be an effective adjunct treatment [15]. This is the only published case of a bipolar depression patient who has been shown to be successfully treated with memantine. The case report we publish supports the clinical efficacy of memantine described by Strzelecki et al.

Despite the overwhelming evidence that memantine does not have an antidepressant effect, our literature review and the reported case still suggest that memantine may nevertheless have some antidepressant effects, particularly in the treatment of bipolar depression in combination with mood stabilizing treatment. Combined with the inconsistency of preclinical and clinical data, it justifies further clinical studies on the possibility of using memantine in the treatment of depression.

In the described by Strzelecki et al., the case study for memantine showed an antidepressant effect when combined with lithium $(1 \mathrm{~g} /$ day $)$, olanzapine $(7.5 \mathrm{mg} /$ day $)$, and mianserin $(60 \mathrm{mg} /$ day). Before adding memantine, this patient took lithium, olanzapine, and mianserin for several weeks without improving his depressive symptoms. It was similar in the case described by us - the patient was unsuccessfully treated for depression with lamotrigine, valproic acid, and amantadine when he started taking memantine. Perhaps memantine in bipolar depression has an antidepressant effect not in monotherapy, but as a method of augmentation of treatment with mood stabilizers. In the studies of bipolar depression that showed a certain antidepressant effect of memantine, it was added to a mood stabilizer [13-16]. This indicates the direction of further clinical trials of memantine as an add-on treatment for mood stabilizing treatment.

In the case described by Strzelecki et al., improvement occurred rapidly at the start of treatment with memantine (at $5 \mathrm{mg}$, the HDRS score fell by $21 \%$ after one week). This is a similar effect seen in the study by Anand et al., where improvement was (only) seen during the titration-up of the memantine dose [13]. However, it cannot be ruled out that the rapid improvement observed at the start of treatment may also have been a placebo effect. In the patient described by us, the titration-up was faster than in the Strzelecki study, and the improvement after 2 weeks of using amantadine in a dose of $20 \mathrm{mg}$ was 35\% in HDRS compared with $15.8 \%$ in the study by Strzelecki et al. The faster dose escalation was well tolerated and perhaps led to a better therapeutic effect after 2 weeks with the target dose of memantine. Interestingly, in the case described by Strzelecki et al., the improvement after 8 weeks of treatment (reduction in HDRS-17 by $47.4 \%$ ) was very similar to the improvement obtained after 7 weeks of using the $20 \mathrm{mg}$ dose (reduction in the HDRS score by $47.1 \%$ ) in the patient described by us. Data from both case studies may indicate efficacy of the $20 \mathrm{mg}$ dose of memantine in the treatment of bipolar depression. In both cases, treatment with memantine was well tolerated.

In our case, the attempt to stop taking memantine caused a deterioration of mood. In the case described by Strzelecki et al., the patient was still in remission of depressive symptoms after the discontinuation of memantine and 6 weeks later, but the authors did not follow-up the patient longer, so it is not known if the improvement was permanent. Perhaps each case must be treated individually and each time the doctor must decide 
whether to stop or maintain the treatment with memantine. Moreover, as there is some evidence of the anti-manic and mood-stimulating effects of memantine, it may be possible that continued treatment with memantine for an extended period of time may have a preventive effect on relapse in BD [16,34-36]. In order to confirm this hypothesis, a clinical trial to assess the effect of the long-term use of memantine on the frequency of relapse of BD episodes is required.

\section{Methods}

The authors decided to review the literature, considering clinical trials, case series, and case reports. PRISMA guidelines were used when preparing this systematic review [37]. Full-text publications available in English were included in the analysis. In each study, at least the baseline and endpoints of the treatment efficacy had to be characterized. The review was conducted independently by two investigators, then their search results were combined and duplicate records were removed.

The following medical databases were searched in the study: PubMed, Scopus, Web of Science, and Google Scholar (effective date 26 March 2021). The search was performed according to the PICO framework ( $\mathrm{P}$-patient, problem, or population; I-intervention; $\mathrm{C}$-comparison, control, or comparator; O-outcomes). During our search, we used the following terms: "bipolar depression" (Title/Abstract), "memantine" (Title/Abstract), "mood stabilizers" (Title/Abstract), "improvement of depressive symptoms" (Title/Abstract), "memantine and depression" (Title/Abstract), "memantine and depression treatment" (Title/Abstract), "monotherapy" (Title/Abstract), and "augmentation" (Title/Abstract).

After obtaining 308 records from the medical databases searched, the same terms were entered in the Google search engine and an additional seven publications were obtained. In total, there were 315 records in the database of articles. After initial review, 252 articles were excluded as they were review articles, editorials, commentaries, or letters to editors. Moreover, publications in which only abstracts were available and publications in a language other than English were also excluded. In this way, 63 articles were obtained, of which 43 were excluded because they were studies in which there was no basic data on group size, or inclusion and exclusion criteria, or after reading it turned out they contain information not related to the topic of the review. The flow diagram of the analysis is presented in Figure 3.

To assess the risk of bias and study quality in quantitative studies, the Effective Public Health Practice Project's (EPHPP) Quality Assessment Tool for Quantitative Studies (QATQS) was used [38,39]. This tool enables quality evaluation of a wide range of study designs, including RCTs, observational studies with and without control groups, and case studies. The instrument contains eight different sections, each with multiple questions, namely: selection bias, study design, confounders, blinding, data collection methods, withdrawals and drop-outs, intervention integrity, and analyses. Each section receives a score of 1 (strong), 2 (moderate), or 3 (weak), and a final score is determined by the number of weak ratings. A strong rating is given to a study if there is no weak component score. A moderate rating is given with one weak component score. A weak rating is given with two or more component rating scores.

Additionally, a case of a 43-year-old patient suffering from BD diagnosed according to ICD-10 since the age of 34, currently presenting symptoms of moderate depression (18 points on Hamilton's 17 points Depression Rating Scale (HDRS-17)), and treated with memantine was described.

\section{Conclusions}

The described case and the analysis of the literature, in our opinion, indicate that despite the ineffectiveness of memantine in recurrent depression, it may be an effective and safe method of augmentation in the treatment of bipolar depression. This warrants further clinical trials adding memantine to drugs that stabilize mood in bipolar depression. 


\section{Patents}

The retrospective case report used data from the outpatient treatment of a 43-year-old man treated by one of the authors (M.K.) for a bipolar depression. The patient's data were anonymized for this report, making it impossible to identify. The patient was informed about the mechanism of action of amantadine, its potential side effects, and the off-label use of drug before starting memantine. Before the treatment, the patient consented to add-on treatment with memantine.

Author Contributions: Conceptualization, M.K.; methodology, M.K. and S.S.; software, S.S. and M.R.; validation, M.K. and K.K.; formal analysis, S.S. and M.R.; investigation, S.S., M.R., A.P., and K.K.; data curation, M.K. and K.K.; writing-original draft preparation, M.K. and S.S.; writingreview and editing, M.K., A.P., and K.K.; visualization, M.K. and A.P.; supervision, M.K. All authors have read and agreed to the published version of the manuscript.

Funding: This research received no external funding.

Institutional Review Board Statement: After consulting with the chairman of the Bioethics Committee of the Medical University of Silesia in Katowice ethical review and approval were waived because a case report does not require the approval of the bioethics committee.

Informed Consent Statement: After consulting with the chairman of the Bioethics Committee of the Medical University of Silesia in Katowice, patient consent was waived as a case report does not require the approval of the bioethics committee.

Data Availability Statement: Data supporting reported results on the treatment of the patient can be found in the author's (M.K.) medical record, and can be obtained upon request from corresponding author.

Conflicts of Interest: The authors declare no conflict of interest.

\section{References}

1. Post, R.M. Treatment of Bipolar Depression. Psychiatr. Clin. N. Am. 2016, 39, 11-33. [CrossRef]

2. Szmulewicz, A.G.; Angriman, F.; Samamé, C.; Ferraris, A.; Vigo, D.; Strejilevich, S.A. Dopaminergic agents in the treatment of bipolar depression: A systematic review and meta-analysis. Acta Psychiatr. Scand. 2017, 135, 527-538. [CrossRef] [PubMed]

3. Blanpied, T.A.; Clarke, R.J.; Johnson, J.W. Amantadine Inhibits NMDA Receptors by Accelerating Channel Closure during Channel Block. J. Neurosci. 2005, 25, 3312-3322. [CrossRef]

4. Lipton, S.A. Pathologically-Activated Therapeutics for Neuroprotection: Mechanism of NMDA Receptor Block by Memantine and S-Nitrosylation. Curr. Drug Targets 2007, 8, 621-632. [CrossRef]

5. Song, X.; Jensen, M.Ø.; Jogini, V.; Stein, R.A.; Lee, C.-H.; Mchaourab, H.S.; Shaw, D.E.; Gouaux, E. Mechanism of NMDA receptor channel block by MK-801 and memantine. Nat. Cell Biol. 2018, 556, 515-519. [CrossRef]

6. Johnson, J.W.; Kotermanski, S.E. Mechanism of action of memantine. Curr. Opin. Pharmacol. 2006, 6, 61-67. [CrossRef] [PubMed]

7. Moriguchi, S.; Ishizuka, T.; Yabuki, Y.; Shioda, N.; Sasaki, Y.; Tagashira, H.; Yawo, H.; Yeh, J.Z.; Sakagami, H.; Narahashi, T.; et al. Blockade of the KATP channel Kir6.2 by memantine represents a novel mechanism relevant to Alzheimer's disease therapy. Mol. Psychiatry 2018, 23, 211-221. [CrossRef]

8. Motawaj, M.; Burban, A.; Davenas, E.; Arrang, J.-M. Activation of Brain Histaminergic Neurotransmission: A Mechanism for Cognitive Effects of Memantine in Alzheimer's Disease. J. Pharmacol. Exp. Ther. 2010, 336, 479-487. [CrossRef]

9. Lu, C.-W.; Lin, T.-Y.; Wang, S.-J. Memantine depresses glutamate release through inhibition of voltage-dependent Ca2+ entry and protein kinase $C$ in rat cerebral cortex nerve terminals: An NMDA receptor-independent mechanism. Neurochem. Int. 2010, 57, 168-176. [CrossRef] [PubMed]

10. Kloc, R.; Luchowska, E.; Wielosz, M.; Owe-Larsson, B.; Urbańska, E.M. Memantine increases brain production of kynurenic acid via protein kinase A-dependent mechanism. Neurosci. Lett. 2008, 435, 169-173. [CrossRef] [PubMed]

11. Sun, D.; Chen, J.; Bao, X.; Cai, Y.; Zhao, J.; Huang, J.; Huang, W.; Fan, X.; Xu, H. Protection of Radial Glial-Like Cells in the Hippocampus of APP/PS1 Mice: A Novel Mechanism of Memantine in the Treatment of Alzheimer's Disease. Mol. Neurobiol. 2015, 52, 464-477. [CrossRef] [PubMed]

12. Kishi, T.; Matsunaga, S.; Iwata, N. A Meta-Analysis of Memantine for Depression. J. Alzheimer's Dis. 2017, 57, 113-121. [CrossRef] [PubMed]

13. Anand, A.; Gunn, A.D.; Barkay, G.; Karne, H.S.; Nurnberger, I.J.; Mathew, S.J.; Ghosh, S. Early antidepressant effect of memantine during augmentation of lamotrigine inadequate response in bipolar depression: A double-blind, randomized, placebo-controlled trial. Bipolar Disord. 2012, 14, 64-70. [CrossRef] 
14. Lee, S.-Y.; Chen, S.-L.; Chang, Y.-H.; Chu, C.-H.; Huang, S.-Y.; Tzeng, N.-S.; Wang, C.-L.; Yeh, T.L.; Lu, R.-B.; Yang, Y.K. Genotype variant associated with add-on memantine in bipolar II disorder. Int. J. Neuropsychopharmacol. 2013, 17, 189-197. [CrossRef] [PubMed]

15. Strzelecki, D.; Tabaszewska, A.; Barszcz, Z.; Józefowicz, O.; Kropiwnicki, P.; Rabe-Jabłońska, J. A 10-Week Memantine Treatment in Bipolar Depression: A Case Report. Focus on Depressive Symptomatology, Cognitive Parameters and Quality of Life. Psychiatry Investig. 2013, 10, 421-424. [CrossRef]

16. Stevens, J.; Bies, R.R.; Shekhar, A.; Anand, A. Bayesian model of Hamilton Depression Rating Score (HDRS) with memantine augmentation in bipolar depression. Br. J. Clin. Pharmacol. 2013, 75, 791-798. [CrossRef] [PubMed]

17. Krzystanek, M.; Pałasz, A. Possibility of a New Indication for Amantadine in the Treatment of Bipolar Depression-Case Series Study. Pharmaceuticals 2020, 13, 326. [CrossRef]

18. Moryl, E.; Danysz, W.; Quack, G. Potential Antidepressive Properties of Amantadine, Memantine and Bifemelane. Pharmacol. Toxicol. 1993, 72, 394-397. [CrossRef]

19. Rogóz, Z.; Skuza, G.; Maj, J.; Danysz, W. Synergistic effect of uncompetitive NMDA receptor antagonists and antidepressant drugs in the forced swimming test in rats. Neuropharmacology. 2002, 42, 1024-1030. [CrossRef]

20. Almeida, R.C.; Souza, D.G.; Soletti, R.C.; López, M.G.; Rodrigues, A.L.S.; Gabilan, N.H. Involvement of PKA, MAPK/ERK and CaMKII, but not PKC in the acute antidepressant-like effect of memantine in mice. Neurosci. Lett. 2006, 395, 93-97. [CrossRef]

21. Réus, G.Z.; Stringari, R.B.; Kirsch, T.R.; Fries, G.R.; Kapczinski, F.; Roesler, R.; Quevedo, J. Neurochemical and behavioural effects of acute and chronic memantine administration in rats: Further support for NMDA as a new pharmacological target for the treatment of depression? Brain Res. Bull. 2010, 81, 585-589. [CrossRef]

22. Quan, M.-N.; Zhang, N.; Wang, Y.-Y.; Zhang, T.; Yang, Z. Possible antidepressant effects and mechanisms of memantine in behaviors and synaptic plasticity of a depression rat model. Neuroscience 2011, 182, 88-97. [CrossRef] [PubMed]

23. Réus, G.Z.; Stringari, R.B.; Ribeiro, K.F.; Ferraro, A.K.; Vitto, M.F.; Cesconetto, P.; Souza, C.T.; Quevedo, J. Ketamine plus imipramine treatment induces antidepressant-like behavior and increases CREB and BDNF protein levels and PKA and PKC phosphorylation in rat brain. Behav. Brain Res. 2011, 221, 166-171. [CrossRef]

24. Amidfar, M.; Réus, G.Z.; Quevedo, J.; Kim, Y.-K.; Arbabi, M. Effect of co-administration of memantine and sertraline on the antidepressant-like activity and brain-derived neurotrophic factor (BDNF) levels in the rat brain. Brain Res. Bull. 2017, 128, 29-33. [CrossRef] [PubMed]

25. Amidfar, M.; Kim, Y.-K.; Wiborg, O. Effectiveness of memantine on depression-like behavior, memory deficits and brain mRNA levels of BDNF and TrkB in rats subjected to repeated unpredictable stress. Pharmacol. Rep. 2018, 70, 600-606. [CrossRef] [PubMed]

26. Li, Z.; Wang, G.; Zhong, S.; Liao, X.; Lai, S.; Shan, Y.; Chen, J.; Zhang, L.; Lu, Q.; Shen, S.; et al. Alleviation of cognitive deficits and high copper levels by an NMDA receptor antagonist in a rat depression model. Compr. Psychiatry 2020, 102, 152200. [CrossRef]

27. Zarate, C.A.; Singh, J.B.; Quiroz, J.A.; De Jesus, G.; Denicoff, K.K.; Luckenbaugh, D.A.; Manji, H.K.; Charney, D.S. A Double-Blind, Placebo-Controlled Study of Memantine in the Treatment of Major Depression. Am. J. Psychiatry 2006, 163, 153-155. [CrossRef]

28. Ferguson, J.M.; Shingleton, R.N. An Open-label, Flexible-Dose Study of Memantine in Major Depressive Disorder. Clin. Neuropharmacol. 2007, 30, 136-144. [CrossRef]

29. Muhonen, L.H.; Lönnqvist, J.; Juva, K.; Alho, H. Double-blind, randomized comparison of memantine and escitalopram for the treatment of major depressive disorder comorbid with alcohol dependence. J. Clin. Psychiatry 2008, 69, 392-399. [CrossRef]

30. Smith, E.G.; Deligiannidis, K.M.; Ulbricht, C.M.; Landolin, C.S.; Patel, J.K.; Rothschild, A.J. Antidepressant augmentation using the N-methyl-D-aspartate antagonist memantine: A randomized, double-blind, placebo-controlled trial. J. Clin. Psychiatry 2013, 74, 966-973. [CrossRef]

31. Omranifard, V.; Shirzadi, E.; Samandari, S.; Afshar, H.; Maracy, M.R. Memantine add on to citalopram in elderly patients with depression: A double-blind placebo-controlled study. J. Res. Med. Sci. 2014, 19, 525-530.

32. Amidfar, M.; Khiabany, M.; Kohi, A.; Salardini, E.; Arbabi, M.; Azizi, M.R.; Zarrindast, M.; Mohammadinejad, P.; Zeinoddini, A.; Akhondzadeh, S. Effect of memantine combination therapy on symptoms in patients with moderate-to-severe depressive disorder: Randomized, double-blind, placebo-controlled study. J. Clin. Pharm. Ther. 2016, 42, 44-50. [CrossRef]

33. Lavretsky, H.; Laird, K.T.; Krause-Sorio, B.; Heimberg, B.F.; Yeargin, J.; Grzenda, A.; Wu, P.; Thana-Udom, K.; Ercoli, L.M.; Siddarth, P. A Randomized Double-Blind Placebo-Controlled Trial of Combined Escitalopram and Memantine for Older Adults With Major Depression and Subjective Memory Complaints. Am. J. Geriatr. Psychiatry 2020, 28, 178-190. [CrossRef] [PubMed]

34. Koukopoulos, A.; Serra, G.; Koukopoulos, A.E.; Reginaldi, D.; Serra, G. The sustained mood-stabilizing effect of memantine in the management of treatment resistant bipolar disorders: Findings from a 12-month naturalistic trial. J. Affect. Disord. 2012, 136, 163-166. [CrossRef] [PubMed]

35. Keck, P.E.; Hsu, H.-A.; Papadakis, K.; Russo, J. Memantine Efficacy and Safety in Patients with Acute Mania Associated with Bipolar I Disorder. Clin. Neuropharmacol. 2009, 32, 199-204. [CrossRef]

36. Serra, G.; De Chiara, L.; Manfredi, G.; Koukopoulos, A.E.; Sani, G.; Girardi, P.; Koukopoulos, A.; Serra, G. Memantine in the management of affective recurrences of bipolar disorders after the discontinuation of long-term lithium treatment: Three case histories. Ther. Adv. Psychopharmacol. 2013, 4, 53-55. [CrossRef]

37. Moher, D.; Liberati, A.; Tetzlaff, J.; Altman, D.G. Preferred Reporting Items for Systematic Reviews and Meta-Analyses: The PRISMA Statement. Ann. Intern. Med. 2009, 151, 264-269. [CrossRef] 
38. Thomas, B.; Ciliska, D.; Dobbins, M.; Micucci, S. A Process for Systematically Reviewing the Literature: Providing the Research Evidence for Public Health Nursing Interventions. Worldviews Evid.-Based Nurs. 2004, 1, 176-184. [CrossRef] [PubMed]

39. Armijo-Olivo, S.; Stiles, C.R.; Hagen, N.A.; Biondo, P.D.; Cummings, G.G. Assessment of study quality for systematic reviews: A comparison of the Cochrane Collaboration Risk of Bias Tool and the Effective Public Health Practice Project Quality Assessment Tool: Methodological research. J. Eval. Clin. Pract. 2010, 18, 12-18. [CrossRef] 